\title{
Diet composition changes in tigerfish of Lake Kariba following an invasion by redclaw crayfish
}

\author{
Lightone Marufu ${ }^{1}$, Tatenda Dalu ${ }^{2,3 *}$, Crispen Phiri ${ }^{4}$ and Tamuka Nhiwatiwa ${ }^{1,5}$ \\ 1 Department of Biological Sciences, University of Zimbabwe, P.O. Box MP 167, Mt. Pleasant, Harare, Zimbabwe \\ 2 Department of Zoology and Entomology, Rhodes University, P.O. Box 94, Grahamstown 6140, South Africa \\ 3 South African Institute for Aquatic Biodiversity, P. Bag 1015, Grahamstown 6140, South Africa \\ 4 Department of Freshwater and Fishery Sciences, Chinhoyi University of Technology, P. Bag 7724, Chinhoyi, Zimbabwe \\ 5 University Lake Kariba Research Station, P.O. Box 48, Kariba, Zimbabwe
}

Received 23 May 2016; Accepted 9 November 2016

\begin{abstract}
The present study used a combination of stable isotope techniques and stomach content analyses to examine the diet and ontogenetic diet shifts of tigerfish, Hydrocynus vittatus, in the Sanyati basin of Lake Kariba, Zimbabwe. We compared tigerfish diet shifts in the presence of an invasive crayfish, Cherax quadricarinatus, with previous studies before invasion. Here, we assessed whether tigerfish now had a preference for $C$. quadricarinatus leading to a shift in its main dietary food sources from cichlids to crayfish. The dominance of cichlids has remained generally high when compared with historical assessments. Stable isotope analyses showed that tigerfish fed on a variety of food sources including those that may be temporarily unavailable. Results of stable isotope analyses also highlighted that $C$. quadricarinatus was now becoming an important food source across all tigerfish size classes. In conclusion, tigerfish in Lake Kariba showed remarkable dietary plasticity and ontogenetic shifts, identified by both stomach content and stable isotope analyses.
\end{abstract}

Key words: SIAR / stable isotopes / cichlids / niche overlap / food web / trophic position / ontogenetic shift

\section{Introduction}

Humans have efficiently transported thousands of species around the world and, with accelerated trade (Dudgeon et al., 2006; Havel et al., 2015; Souty-Grosset et al., 2016), the rate of introductions has increased over time (Strayer, 2010; Souty-Grosset et al., 2016). Aquatic ecosystems seem at particular risk from invasive species due to the threats to biodiversity and human needs for water resources (Havel et al., 2015). To assess the progression of invasive species requires researchers and environmental managers to monitor the environment and carry out baseline studies. The information generated from these baseline studies becomes useful in developing adaptive management responses that may help to control the invasive species (Holling, 1978; Jussila et al., 2015; Wendler et al., 2015).

In Lake Kariba, feral populations of the invasive redclaw crayfish, Cherax quadricarinatus (von Martens, 1868) became establishedby 2009 (Marufu et al., 2014). C. quadricarinatus is a freshwater crayfish that originates

\footnotetext{
*Corresponding author: dalutatenda@yahoo.co.uk
}

from northern Australia and Papua New Guinea and has been widely introduced to many countries for aquaculture purposes (ISP, 2016). Introduction of crayfish has been associated with decreases in vegetation, detritus, macroinvertebrates and displacement of benthic fish (Feminella and Resh, 1989; Sala et al., 2000; Kreps et al., 2015). C. quadricarinatus may provide a new food source for predators in Lake Kariba as has been observed in the Kafue River, Zambia (Tyser and Douthwaite, 2014). Information on how the presence of this invasive crayfish may affect the diet of some of the predators in Lake Kariba still remains tentative. One predator that may benefit from the presence of $C$. quadricarinatus in Lake Kariba is the tigerfish (H. vittatus).

$H$. vittatus is a piscivore and popular angling species and can grow up to $70 \mathrm{~cm}$ fork length and a weight of $15 \mathrm{~kg}$. Previous studies (i.e., Matthes, 1968; Mhlanga, 2003; Dalu et al., 2012) have described the diets of tigerfish, which primarily consists of fish and macroinvertebrates. The recent reports of the establishment of C. quadricarinatus populations in the Sanyati basin of Lake Kariba (Marufu et al., 2014) make it a potential new prey for $H$. vittatus. 
Stomach content analysis is the traditional and most convenient way of understanding the diet of animals through the quantification of trophic relationships (Hyslop, 1980; Kadye and Booth, 2012). However, this method is problematic as it does not adequately consider spatial and temporal variation when drawing dietary inference (Pinnegar and Polunin, 1999; Mustamäki et al., 2014) and can underestimate the consumption of highly digestible material (Pinnegar and Polunin, 1999; Mustamäki et al., 2014). Stomach content analysis may provide "snap shots" of dietary items in the gut, while the use of stable isotopes of carbon and nitrogen in animal tissues integrate dietary components over a much longer period of time (Hesslein et al., 1993; Kadye and Booth, 2012). Although stable isotope analysis does not provide full details of dietary preferences, it provides an estimate of an organism's preferred diet, which is less temporally biased than that obtained from stomach content analysis (Hesslein et al., 1993; Mustamäki et al., 2014). Furthermore, the contribution of items, which are poorly quantified by stomach content analysis, such as detritus and small organisms, may be revealed through stable isotope analysis (Hesslein et al., 1993; Pinnegar and Polunin, 1999).

Stable isotope analysis, using carbon and nitrogen stable isotope composition $\left(\delta^{13} \mathrm{C}\right.$ and $\left.\delta^{15} \mathrm{~N}\right)$, has proven to be a powerful and useful tool in investigating and reconstructing dietary patterns and characterizing trophic relationships (Layman et al., 2012). It has also proven a useful tool in elucidating patterns of resource allocation (Bergamino et al., 2014) and in the construction of food webs within ecosystems because it provides time- and space-integrated insights into trophic relationships among organisms (Hansson et al., 1997; Fry and Davis, 2015). This technique is particularly suited to determining the relative contributions of two isotopically distinct sources of organic matter to the diets of consumers and yields time-integrated information of assimilated not just ingested foods (Vander Zanden et al., 1997; Layman et al., 2012; Carvalho et al., 2015). The foundation of stable nitrogen isotopes is that the ratio between ${ }^{15} \mathrm{~N}$ and ${ }^{14} \mathrm{~N}$ in biological tissues is variable, and the proportion of ${ }^{15} \mathrm{~N}$ usually increases with the increasing trophic level (Hansson et al., 1997). On the other hand, stable carbon isotopes $\left({ }^{13} \mathrm{C}\right)$ are known to fractionate little between energy transfers; hence, they are commonly used to quantify food sources and energy flow in aquatic systems (Fry and Davis, 2015). Moreover, the variances of stable ${ }^{15} \mathrm{~N}$ and ${ }^{13} \mathrm{C}$ isotopes reflect changes in diet, and can therefore be used as a measure of niche width (Peterson and Fry, 1987; Post et al., 2007; Mustamäki et al., 2014).

The present study used a combination of stomach content and stable isotope analyses to examine the diet of tigerfish, H. vittatus, in Kasese Bay, Sanyati basin of Lake Kariba, Zimbabwe. Stomach contents give a snap shot and may be misleading, while stable isotopes provide information on medium to long-term diet, making a dual approach more suitable. We compared tigerfish diet shifts in the presence of an invasive crayfish, C. quadricarinatus, with previous studies (i.e., Kenmuir, 1971, 1973; Takano and Subramaniam, 1988; Mhlanga, 2003) before invasion. Here, we assessed whether the tigerfish now prefer C. quadricarinatus leading to a shift from cichlids based on reports by Marufu et al. (2014). Crayfish average CPUE (catch per unit effort) per cage/trap increased from zero in 2008 to $\sim 7$ in 2014 (L. Marufu, personal communication). We hypothesized that: (i) different tigerfish standard length classes will have different dietary needs as highlighted by previous studies; and (ii) tigerfish will consume the most abundant food source, with the invasive crayfish forming a significant dietary food item.

\section{Materials and methods}

\section{Study area}

The study was carried out in Lake Kariba's Kasese Bay, Sanyati basin (Fig. 1). Lake Kariba is a man-made reservoir that is shared between Zambia and Zimbabwe and occurs at latitudes $16.5^{\circ}-18^{\circ} \mathrm{S}$, and longitudes $27^{\circ}-29^{\circ} \mathrm{E}$ (Fig. 1). It was built between 1952 and 1959 by damming the Zambezi River for hydroelectricity generation (Coche, 1974). The lake's surface area is 4364 $\mathrm{km}^{2}$, total length is $276 \mathrm{~km}$, and it has a mean width and depth of $19 \mathrm{~km}$ and $29 \mathrm{~m}$, respectively (Coche, 1974). Biological samples, i.e., crayfish, fish, plants and invertebrates, were collected from five locations in Kasese Bay, Sanyati basin of Lake Kariba, Zimbabwe (Fig. 1).

\section{Sample collection}

All animals were collected as humanely as possible, with fish and crayfish being immediately sacrificed by severing the central nervous system with their eyes closed with a towel. Fish were caught using seine nets $(50 \mathrm{~m}$ length, $1.6 \mathrm{~m}$ width, $5 \mathrm{~mm}$ mesh size). The weight ( $\mathrm{g}$ ) and standard length (SL; cm) were measured. Tigerfish stomachs were removed and preserved in $70 \%$ ethanol for stomach content analysis. The tigerfish were divided into three standard length (SL) classes: $<20 \mathrm{~cm}, 20-30 \mathrm{~cm}$ and $>30 \mathrm{~cm}$.

Crayfish were caught using opera house trap nets (rectangular frame $70 \times 30 \mathrm{~cm}^{2}, 3 \mathrm{~mm}$ mesh), laid approximately $10 \mathrm{~m}$ apart in the evening and removed the following morning. Macroinvertebrate samples were collected using a nylon hand net $(500 \mu \mathrm{m}$ mesh size, $30 \times 30 \mathrm{~cm}^{2}$ dimension) and zooplankton (i.e., Cladocerans and copepods) were collected using a plankton net ( $40 \mathrm{~cm}$ diameter, $63 \mu \mathrm{m}$ mesh size).

For sediment, four independent surface samples were collected at about $1-2 \mathrm{~cm}$ depth using a grab sampler and placed into sterile plastic bags for laboratory analysis. Macrophytes (i.e., Eichhornia crassipes, Lagorosiphon major, Pistia stratiotes, Potamogeton pectinatus, Salvinia molesta, Vallisneria aethiopica), leaves and detritus obtained from the surface sediment were collected by hand. 


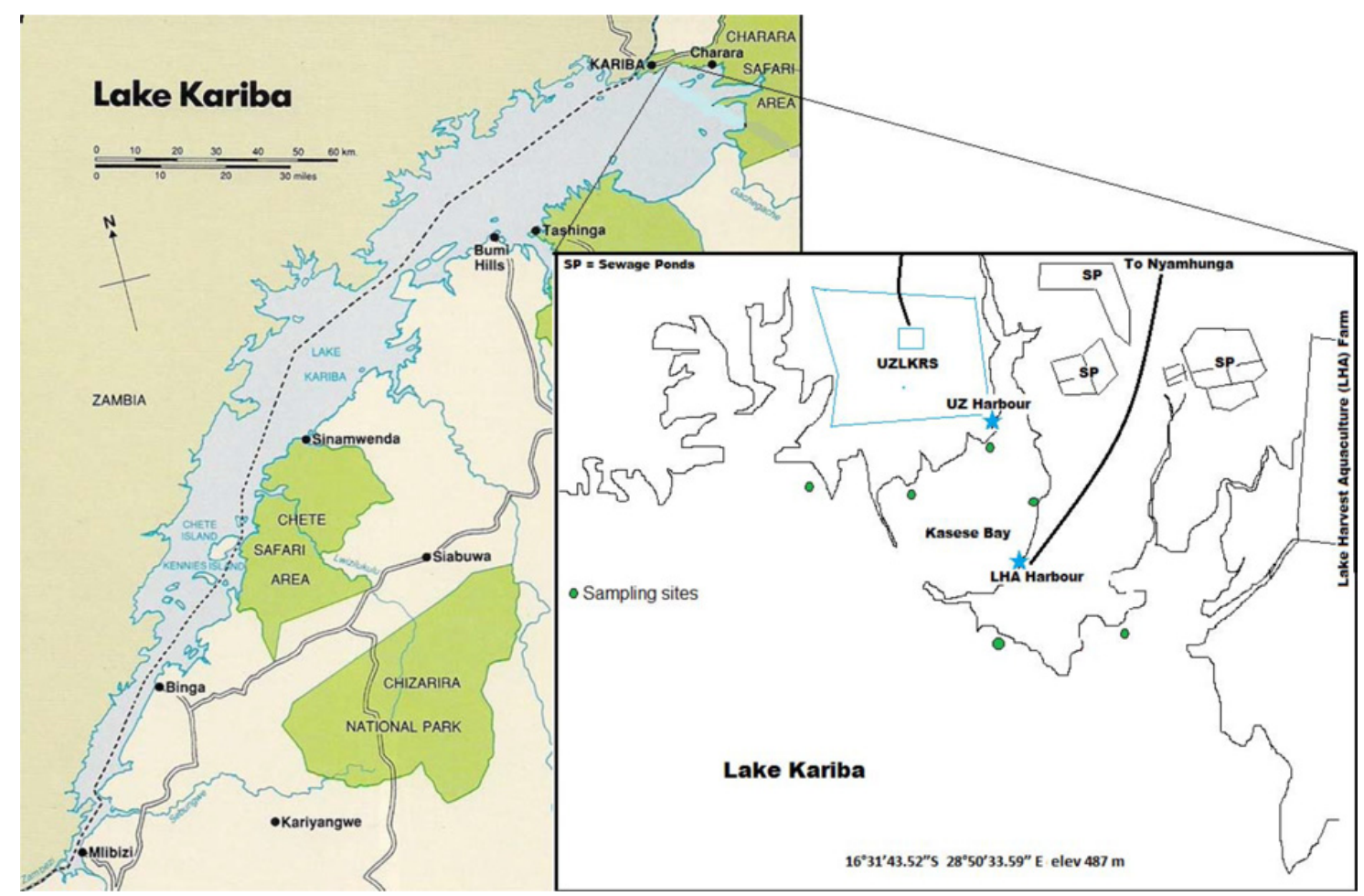

Fig. 1. Location of the sampling along Kasese Bay, Lake Kariba, Zimbabwe.

All samples were placed in separate labelled ziplock bags and stored on ice in the field. All samples were immediately dried upon arrival at the laboratory.

\section{Stable isotope sample processing}

For stable isotope analysis, detritus, seven different fish species, four macroinvertebrate families and zooplankton (i.e., Cladocera and copepods combined) were collected (Table 1). Fish white muscle close to the caudal fin and crayfish abdomen muscle tissue samples $\left(1.5 \times 1.5 \mathrm{~cm}^{2}\right)$ were cut out and immediately placed on ice in the field. Detritus and sediment samples were collected at each sampling station. All samples were collected in replicate $(n=4-17)$, sorted in the field, and placed in separate containers on ice. In the laboratory, all samples were placed in aluminium foil envelopes and oven dried at $60^{\circ} \mathrm{C}$ for $48 \mathrm{~h}$. The dried samples were further ground to a fine homogeneous powder using a mortar and pestle.

Dried sediment samples (1 mg) were first acidified according to the method of Dalu et al. (2016). Aliquots of approximately $0.6-0.7 \mathrm{mg}$ (animal tissues) and $1-1.2 \mathrm{mg}$ (detritus) were weighed into tin capsules pre-cleaned in toluene. Stable isotope analysis was done on a Flash EA 1112 Series coupled to a Delta V Plus stable light isotope ratio mass spectrometer via a ConFlo IV system (Thermo Fischer, Bremen, Germany). Standards (Merck Gel: $\quad \delta^{13} \mathrm{C}=-20.57 \%, \quad \delta^{15} \mathrm{~N}=6.8 \%, \quad \mathrm{C} \%=43.83$, $\mathrm{N} \%=14.64$ ) and a blank sample were run after every 12 unknown samples. All results were referenced to Vienna
Pee-Dee Belemnite for carbon isotope values, and to air for nitrogen isotope values. Results were expressed in delta notation using a per mille scale from the standard equation:

$$
\delta X(\% 0)=\left[\frac{\left(R_{\text {sample }}-R_{\text {standard }}\right)}{R_{\text {standard }}-1}\right] \times 1000
$$

where $X={ }^{15} \mathrm{~N}$ or ${ }^{13} \mathrm{C}$ and $R$ represents ${ }^{15} \mathrm{~N} /{ }^{14} \mathrm{~N}$ or ${ }^{13} \mathrm{C} /{ }^{12} \mathrm{C}$, respectively. Average analytical precision was $<0.15 \%$ for $\delta^{13} \mathrm{C}$ and $<0.1 \%$ or $\delta^{15} \mathrm{~N}$.

The trophic positions (TP) of consumers (fish and crayfish) in the lake were estimated using a formula proposed by McCutchan et al. (2003), with a zooplankton baseline:

$$
\mathrm{TP}=\left(\frac{\delta^{15} \mathrm{~N}_{\text {consumer }}-\delta^{15} \mathrm{~N}_{\text {invertebrates }}}{2.54+2}\right)
$$

where $\delta^{15} \mathrm{~N}_{\text {consumer }}$ is the measured consumer $\delta^{15} \mathrm{~N}$ for which TP needs to be estimated and $\delta^{15} \mathrm{~N}_{\text {invertebrates }}$ is the average $\delta^{15} \mathrm{~N}$ of the primary consumer, in this case zooplankton and 2.54 is the trophic fractionation for $\delta^{15} \mathrm{~N}$ (Vanderklift and Ponsard, 2003). The level 2 was consequently attributed, empirically, to the invertebrate, i.e., Caridina nilotica.

\section{Stomach content analysis and historical assessments}

In the laboratory, the contents of each tigerfish stomach were examined under a dissection microscope. The percentage fullness of each stomach was estimated 
Table 1. Mean stable isotope values $( \pm \mathrm{SD})$ of $\delta^{15} \mathrm{~N}, \delta^{13} \mathrm{C}$ and $\mathrm{C}: \mathrm{N}$ ratios for sampled aquatic organisms in Kasese Bay, Sanyati basin, Lake Kariba.

\begin{tabular}{|c|c|c|c|c|c|c|c|c|c|}
\hline & \multirow{2}{*}{$\begin{array}{c}\text { Length } \\
\text { range }(\mathrm{cm})\end{array}$} & \multirow[b]{2}{*}{$n$} & \multirow{2}{*}{$\begin{array}{l}\text { Trophic } \\
\text { position }\end{array}$} & \multicolumn{2}{|c|}{$\delta^{15} \mathrm{~N}(\%)$} & \multicolumn{2}{|c|}{$\delta^{13} \mathrm{C}(\% 0)$} & \multicolumn{2}{|c|}{$\mathrm{C}: \mathrm{N}$} \\
\hline & & & & $\overline{\text { Mean }}$ & $\mathrm{SD}$ & Mean & $\mathrm{SD}$ & Mean & SD \\
\hline \multicolumn{10}{|l|}{ Tigerfish } \\
\hline Hydrocynus vittatus $\mathrm{SL}<20 \mathrm{~cm}$ & $5.5-19.0$ & 17 & 3.09 & 6.6 & 0.8 & -20.9 & 0.6 & 4.4 & 0.4 \\
\hline Hydrocynus vittatus SL $20-30 \mathrm{~cm}$ & $21.4-29.2$ & 13 & 3.57 & 7.8 & 0.6 & -20.8 & 1.0 & 4.6 & 0.3 \\
\hline Hydrocynus vittatus $\mathrm{SL}>30 \mathrm{~cm}$ & $31.8-43.1$ & 12 & 3.95 & 8.8 & 1.0 & -21.2 & 0.9 & 4.7 & 0.5 \\
\hline \multicolumn{10}{|l|}{ Prey fish } \\
\hline Brycinus imberi & $4.9-5.8$ & 5 & 3.38 & 7.3 & 0.4 & -22.6 & 1.1 & 4.4 & 0.1 \\
\hline Limnothrissa miodon & $3.1-5.4$ & 9 & 3.43 & 7.5 & 0.4 & -22.7 & 1.0 & 4.4 & 0.1 \\
\hline Oerochromis niloticus & $7.5-18$ & 6 & 2.85 & 6.0 & 1.4 & -19.5 & 0.8 & 4.2 & 0.3 \\
\hline Pharyngochromis acuticeps & $3.4-14.8$ & 10 & 3.61 & 7.2 & 0.7 & -20.3 & 1.2 & 4.4 & 0.1 \\
\hline Serranochromis macrocephalus & $8-33.5$ & 4 & 3.61 & 7.9 & 0.7 & -20.5 & 1.1 & 4.3 & 0.1 \\
\hline Coptodon rendalli & $4.9-23.1$ & 14 & 3.16 & 6.8 & 0.6 & -17.3 & 1.6 & 4.4 & 0.3 \\
\hline \multicolumn{10}{|l|}{ Macroinvertebrates } \\
\hline Cherax quadricarinatus & $4.1-9.2$ & 17 & 2.74 & 5.7 & 0.5 & -20.7 & 1.1 & 4.3 & 0.3 \\
\hline Notonecta sp. & & 5 & & 3.7 & 0.9 & -20.5 & 1.0 & 5.3 & 0.3 \\
\hline Lestes sp. & & 5 & & 11.5 & 0.9 & -21.2 & 0.6 & 5.9 & 1.4 \\
\hline Caridina nilotica & & 5 & & 3.8 & 0.5 & -21.6 & 1.0 & 6.2 & 0.8 \\
\hline \multicolumn{10}{|l|}{ Plankton } \\
\hline Zooplankton & $0.1-0.2$ & 5 & & 3.0 & 1.2 & -21.6 & 1.6 & 7.3 & 0.4 \\
\hline \multicolumn{10}{|l|}{ Plants } \\
\hline Detritus & & 5 & & 5.5 & 2.1 & -18.7 & 1.9 & 28.0 & 0.3 \\
\hline Eichhornia crassipes & & 5 & & 7.3 & 2.9 & -26.5 & 0.8 & 25.1 & 7.5 \\
\hline Pistia stratiotes & & 5 & & 6.8 & 1.1 & -13.0 & 0.8 & 56.2 & 11.1 \\
\hline Potamogeton pectinatus & & 5 & & 5.0 & 1.3 & -17.6 & 7.5 & 43.0 & 17.2 \\
\hline Salvinia molesta & & 5 & & 7.6 & 1.2 & -23.4 & 6.7 & 28.1 & 16.4 \\
\hline Vallisineria aethiopica & & 5 & & 5.0 & 0.8 & -16.1 & 1.9 & 26.3 & 3.1 \\
\hline Lagorasiphon major & & 5 & & 6.7 & 1.0 & -12.9 & 0.8 & 32.6 & 2.4 \\
\hline
\end{tabular}

and the food items were removed into a petri dish for identification. The food items were classified into broad taxonomic groups or lowest taxonomic resolution possible.

The number of tigerfish with a particular food item was recorded (occurrence) and the volume of each food item was estimated visually using a method by Zengeya and Marshall (2007). The frequency of occurrence of each food item was determined by calculating the percentage of stomachs containing a particular food item out of the total stomachs containing food according to Hyslop (1980); Dalu et al. (2012) and Kadye and Booth (2012). The frequency of occurrence and index of preponderance (IP) were calculated for each tigerfish size class (Baskar et al., 2012).

A systematic literature search for tigerfish diet in Lake Kariba, unrestricted by publication year in the academic search engines such as Google Scholar, Scopus and Web of Science was carried out. We undertook a systematic literature search, unrestricted by publication year, using the terms "Hydrocynus vittatus", "H. vittatus diet", " $H$. vittatus feeding habitats", " $H$. vittatus stomach contents", " $H$. vittatus feeding habitats", " $H$. vittatus", " $H$. vittatus diet", " $H$. vittatus stomach contents", "tigerfish", "tigerfish diet", "tigerfish stomach contents", "tigerfish feeding habitats", and combined with the terms "Lake Kariba", "Kariba", "Sanyati" and "Sanyati basin". We identified four papers that were useful for the historical assessment: Kenmuir (1971, 1973); Takano and
Subramaniam (1988) and Mhlanga (2003) as these were all carried out within the Sanyati basin of Lake Kariba, where the current study was performed and where the crayfish have invaded. The papers provide a decadal change in the tigerfish diet.

\section{Data analysis}

The tigerfish size class stable carbon $\left(\delta^{13} \mathrm{C}\right)$, stable nitrogen $\left(\delta^{15} \mathrm{~N}\right)$ and $\mathrm{C}: \mathrm{N}$ ratio values were compared by means of a one-way analysis-of-variance (ANOVA) test. Linear regressions were used to determine the relationships among tigerfish standard length, weight, $\delta^{13} \mathrm{C}, \delta^{15} \mathrm{~N}$ and $\mathrm{C}: \mathrm{N}$ in fish muscle tissues. All analyses were carried out using SPSS 16.0 (SPSS Inc., 2007)

Bayesian stable isotope analyses in R (SIAR; Parnell et al., 2010) models were used to assess the relative proportions of different basal food sources (organic matter) and prey (animals) in the diet of tigerfish. Some of the basal food sources (i.e., Caridina nilotica + Notonecta sp. and Limnothrissa miodon + Brycinus imberi) were grouped when the isotopic signatures were found to be similar. The Bayesian SIAR model incorporates uncertainty and variation in parameters (Parnell et al., 2010). Fractionation factors of $\delta^{15} \mathrm{~N} 2.54 \pm 0 \cdot 11$ and $\delta^{13} \mathrm{C}$ $0.4 \pm 1.3$ were used for all animals (Vanderklift \& Ponsard, 2003; Post et al., 2007). The SIBER (Stable Isotope Bayesian Ellipses in R) model in SIAR was then 
employed to analyse the isotopic niche width and overlap among the tigerfish classes using their $\delta^{13} \mathrm{C}$ and $\delta^{15} \mathrm{~N}$ values (Layman et al., 2007; Jackson et al., 2011). Convex hull areas and ellipses represent the calculated isotopic niche breadths and widths for all individuals, as described by Jackson et al. (2011).

\section{Results}

Of the 118 tigerfish caught, 80 had food items in their stomachs. The three tigerfish standard length classes, $<20 \mathrm{~cm}(n=59), 20-30 \mathrm{~cm}(n=47)$ and $>30 \mathrm{~cm}(n=12)$, had mean weights of $56.8 \pm 39.7,260.1 \pm 115.9$ and $780.9 \pm 628.5 \mathrm{~g}$ and mean lengths of $13.9 \pm 3.6,24.4 \pm 3.3$ and $32.1 \pm 4.3 \mathrm{~cm}$, respectively. Stomach content data showed the importance of crayfish in large tigerfish, with cichlids (i.e., Pseudocrenilabrus philander, Pharyngochromis acuticeps and Oreochromis niloticus) being the most abundant food source in all tigerfish SL classes (Table 2). Some cannibalism was observed in the $20-30 \mathrm{~cm}$ tigerfish size class $(20-30 \mathrm{~cm}$ size class, IP $=0.44)$. A historical assessment of tigerfish diet from previous studies showed a change from 1969 to present, whereby the dominance of dietary items in tigerfish changed from Cichlids to Cichlids + Clupeids and then Cichlid + Parastacidae (redclaw crayfish C. quadricarinatus) (Table 3). When the tigerfish were separated into their different size groups in our present study, crayfish was found to be the dominant prey in large tigerfish $(>30 \mathrm{~cm})$ (Tables 2 and 3 ).

Tigefish $\delta^{15} \mathrm{~N}$ values were enriched, with crayfish, C. quadricarinatus, having low $\delta^{15} \mathrm{~N}$ values (Table 1). Significant differences in $\delta 13 C$ values $(F(2,39)=23.11$, $P<0.001)$ were observed among tigerfish classes, suggesting that they utilized different food sources. The $\delta 15 \mathrm{~N}$ $(F(2,39)=0.69, P=0.51)$ and $\mathrm{C}: \mathrm{N}$ ratio $(F(2,39)=1.78$, $P=0.18)$ were found to be similar for the different tigerfish classes.

Mixing models showed an ontogenetic dietary shift in tigerfish from a diet with zooplankton, fish and macroinvertebrates to a fish-dominated diet in large tigerfish. Tigerfish $<20 \mathrm{~cm}$, fed mostly on a combination of crayfish $(14.3 \%)$ and zooplankton (51.8\%; Fig. 2, Table S1). Tigerfish in the $20-30 \mathrm{~cm}$ class fed mainly on crayfish $(26.1 \%)$ and Caridina nilotica + Notonecta sp. (23.2\%), while large tigerfish $>30 \mathrm{~cm}$, fed mostly on L. miodon and B. imberi $(21.3 \%)$ and Caridina nilotica + Notonecta $\mathrm{sp}$. $(19.1 \%)$. Levels of cannibalism were observed mostly in the 20-30 and $>30 \mathrm{~cm}$ classes. The consumption of the invasive $C$. quadricarinatus ranged from 14.3 to $26.13 \%$ (Fig. 2).

The $\delta^{15} \mathrm{~N}$ values significantly increased with tigerfish standard length and weight, with significant relationships being observed for $\delta^{15} \mathrm{~N}$ values with weight $\left(y=0.004 x+6.695 ; \quad F_{(1,40)}=27.59, \quad R=0.64, P<0.001\right)$ and standard length $\left(y=0.085 x+5.624 ; F_{(1,40)}=44.38\right.$, $R=0.73, \quad P<0.001$; Fig. 3). Although these results suggest that habitat and trophic differences may be
Table 2. The frequency of occurrence (\%) and index of preponderance (IP) in tigerfish Hydrocynus vittatus standard length classes; $<20 \mathrm{~cm}, 20-30 \mathrm{~cm}$ and $>30 \mathrm{~cm}$ from Lake Kariba. Cichlids were mostly Pseudocrenilabrus philander, Pharyngochromis acuticeps and Oreochromis niloticus.

\begin{tabular}{lccc}
\hline Food item & \multicolumn{3}{c}{ IP } \\
\cline { 2 - 4 } & $<20 \mathrm{~cm}$ & $20-30 \mathrm{~cm}$ & $>30 \mathrm{~cm}$ \\
\hline$N$ & 38 & 39 & 9 \\
Mormyrus longirostris & 0.28 & 0.83 & \\
Limnothrissa miodon & 13.13 & 0.37 & \\
Hydrocynus vittatus & & 0.44 & \\
Cichlids & 75.53 & 95.39 & 17.33 \\
Bones and scales & 3.41 & 2.32 & \\
Cherax quadricarinatus & 0.05 & 0.44 & 82.67 \\
Invertebrates & 7.38 & 0.14 & \\
Plant material & 0.21 & 0.07 & \\
\hline
\end{tabular}

responsible for the observed variation in tigerfish body size, no relationship was found regarding the $\delta^{13} \mathrm{C}$ values with the weight and standard length $(P>0.05)$. A weak significant relationship $\left(y=0.0129 x+4.229 ; F_{(1,40)}=4.22\right.$, $R=0.31, P=0.047$ ) was observed for $\mathrm{C}: \mathrm{N}$ ratios and tigerfish standard length (Fig. 3).

\section{Discussion}

The invasion of an ecosystem by a new species often implies profound changes in species interactions that can have far reaching ecological implications. Lake Kariba, like many other waterbodies has not been immune to species introductions in the past, but the recent redclaw crayfish introduction has raised serious concerns because of the destructive nature of this species. Studies done elsewhere on invasive crustaceans showed destructive effects on ecosystems by signal crayfish Pacifastacus leniusculus and the bloody-red mysid Hemimysis anomala, respectively (Hudina et al., 2015; Iacarella et al., 2015). Trophic relationships can easily be affected by species introductions and studying these can provide an important insight into the role of new invasive species in an ecosystem. This study investigated predator-prey relations by investigating the diet of an apex predator, $H$. vittatus, following the introduction of the invasive crayfish, C. quadricarinatus in Lake Kariba. The only possibly significant ontogenic shift towards crayfish (Cherax) seems to be in fish $>30 \mathrm{~cm}$ in length, based on the stomach content data.

The results of the present study, based on both stomach and stable isotope analyses, showed that insect and "other invertebrate" occurrence and/or incidence was highly variable and possibly seasonal. This is highlighted by the low occurrences in previous studies, $\sim 5 \%$ of the stomachs examined by Matthes (1968), 5-18\% in Kenmuir (1971, 1973), 2\% in Mhlanga (2003), 11-21.5\% in Takano and Subramaniam (1988) and 0-26\% in the present study.

In contrast to stomach content observations, stable isotope analysis showed that L. miodon is still the 
Table 3. Frequency of occurrence (\%) of different food items in various standard length classes of tigerfish Hydrocynus vittatus for years 1969-2014. Parastacidae - redclaw crayfish, Cherax quadricarinatus family.

\begin{tabular}{|c|c|c|c|c|c|c|c|c|c|c|c|}
\hline \multirow[b]{2}{*}{ Length (cm) } & \multirow{2}{*}{$\frac{1969-70^{\mathrm{a}}}{-}$} & \multirow{2}{*}{$\frac{1970-71^{\mathrm{b}}}{-}$} & \multicolumn{3}{|c|}{$1983-85^{\mathrm{c}}$} & \multicolumn{3}{|c|}{$1994-97^{\mathrm{d}}$} & \multicolumn{3}{|c|}{$2014^{\mathrm{e}}$} \\
\hline & & & $<20$ & $20-30$ & $>30$ & $<23$ & $23-33$ & $>33$ & $<20$ & $20-30$ & $>30$ \\
\hline Clupeidae & 2 & 41 & 75 & 65 & 50 & 43 & 68 & 50 & 21 & $<1$ & 0 \\
\hline Alestidae & 24 & 10 & 0 & $<1$ & $<1$ & 7 & 2 & 3 & 0 & 5 & 0 \\
\hline Cichlidae & 34 & 15 & 41.2 & 39 & 46 & 38 & 18 & 36 & 44 & 64 & 33 \\
\hline Other fish & 1 & 1 & 0 & 0 & 2.1 & 10 & 11 & 14 & & & \\
\hline Parastacidae & & & & & & & & & 3 & 5 & 67 \\
\hline Invertebrates & 5 & 18 & 15 & 11 & 21.5 & 2 & & & 26 & 7 & 0 \\
\hline
\end{tabular}

Sources. ${ }^{\mathrm{a}}$ Kenmuir (1971).

${ }^{\mathrm{b}}$ Kenmuir (1973).

${ }^{\mathrm{c}}$ Takano and Subramaniam (1988).

${ }^{\mathrm{d}}$ Mhlanga (2003).

ePresent study

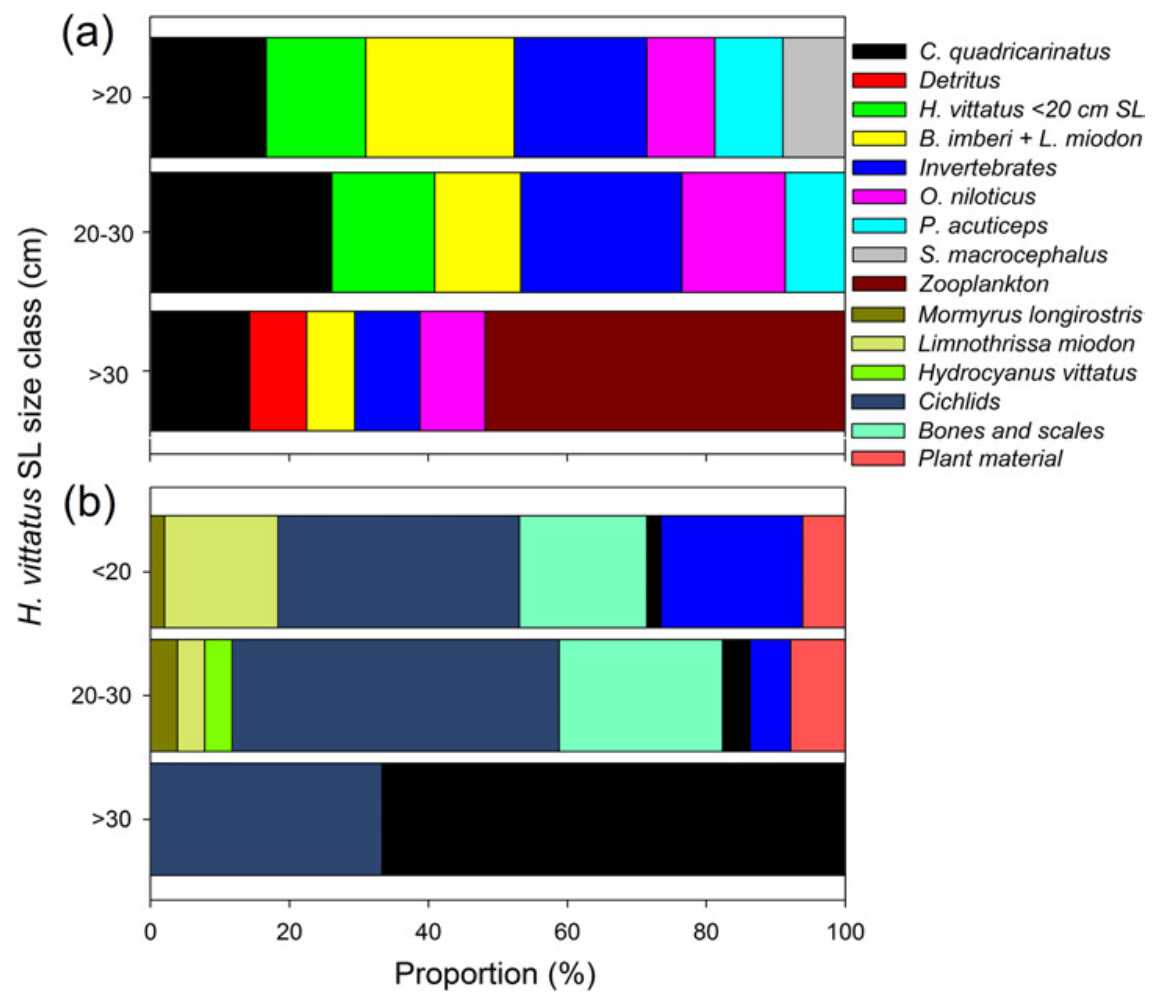

Fig. 2. Relative mean percentage contributions, as estimated by (a) SIAR and (b) stomach content analysis of different food sources to tigerfish in Sanyati basin, Lake Kariba. SL, standard length.

dominant prey consumed by tigerfish. Mhlanga (2003) highlighted that tigerfish in Lake Kariba preferred to feed mostly on L. miodon and cichlids, which was similar to the results found in this study. The large tigerfish $(>30 \mathrm{~cm})$, had high $\delta^{15} \mathrm{~N}$ values implying that they occupied a higher TP. Cichlids occurred in all tigerfish stomachs examined in the current study and Cichlid occurrences were higher than those reported by Mhlanga (2003) but similar to studies by Takano and Subramaniam (1988).

In Malilangwe reservoir, Dalu et al. (2012) found that the most dominant food item for tigerfish were cichlids as these formed $\sim 46 \%$ of the fish community (Dalu et al., 2013), while in Lake Kariba, L. miodon was an important food source as it dominated the pelagic environment
(Sanyanga, 1996; Mhlanga, 2003). Therefore, these results demonstrate that tigerfish showed remarkable dietary plasticity. Previous studies (e.g., Matthes, 1968; Takano and Subramaniam, 1988; Mhlanga, 2003) have noted that S. zambezensis, an abundant fish (Sanyanga, 1996) and similarly, the now abundant redclaw crayfish, is rarely found in the tigerfish diet based on stomach content analysis. The synodontids and crayfish are both bottomdwellers and nocturnal, often living amongst rocks in deep water where they can avoid predators (Gosse, 1986; Ahyong and Yeo, 2007). Although large tigerfish may have evolved ways of dealing with them, the optimal foraging theory and the question of handling time may be important in answering this ecological question. 
A
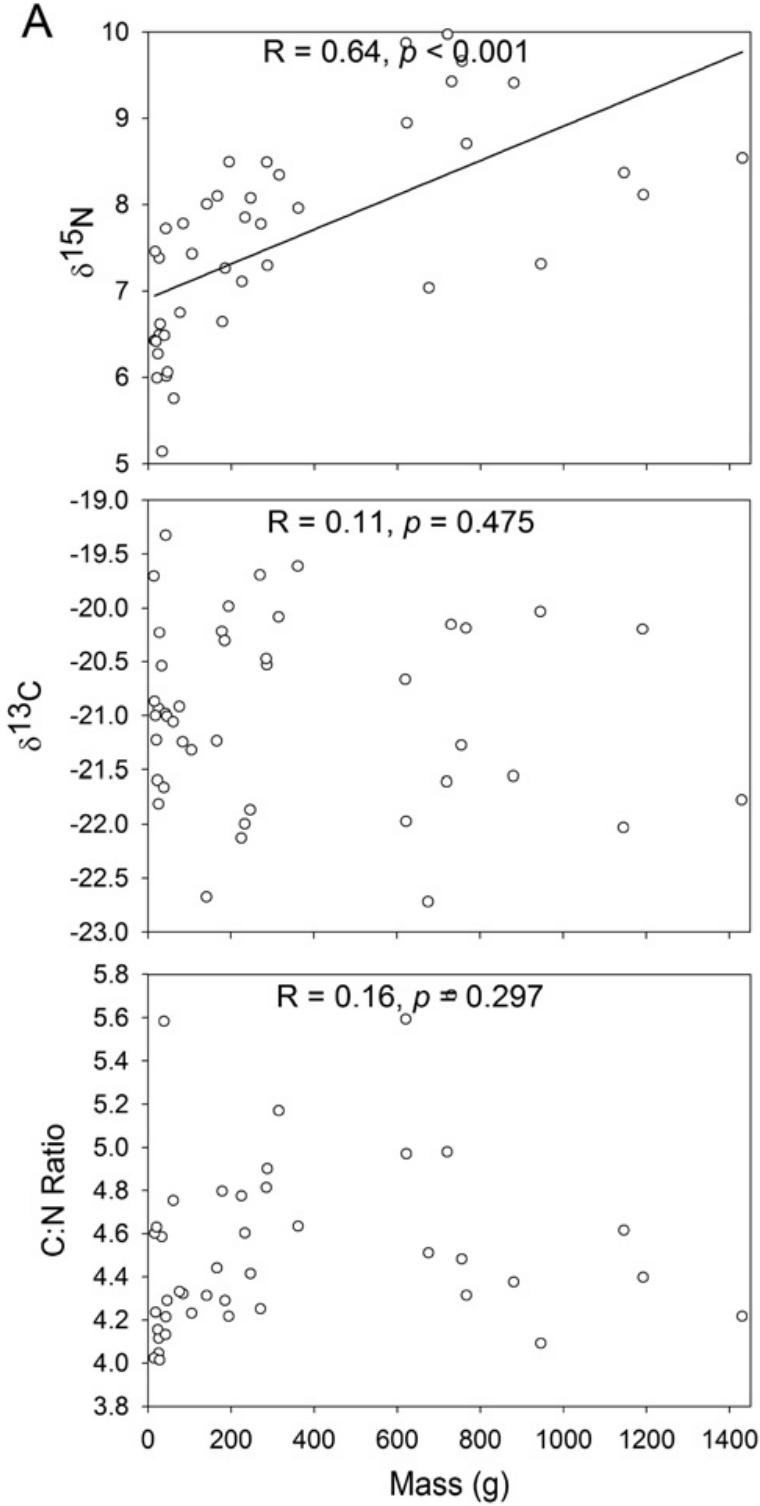

B
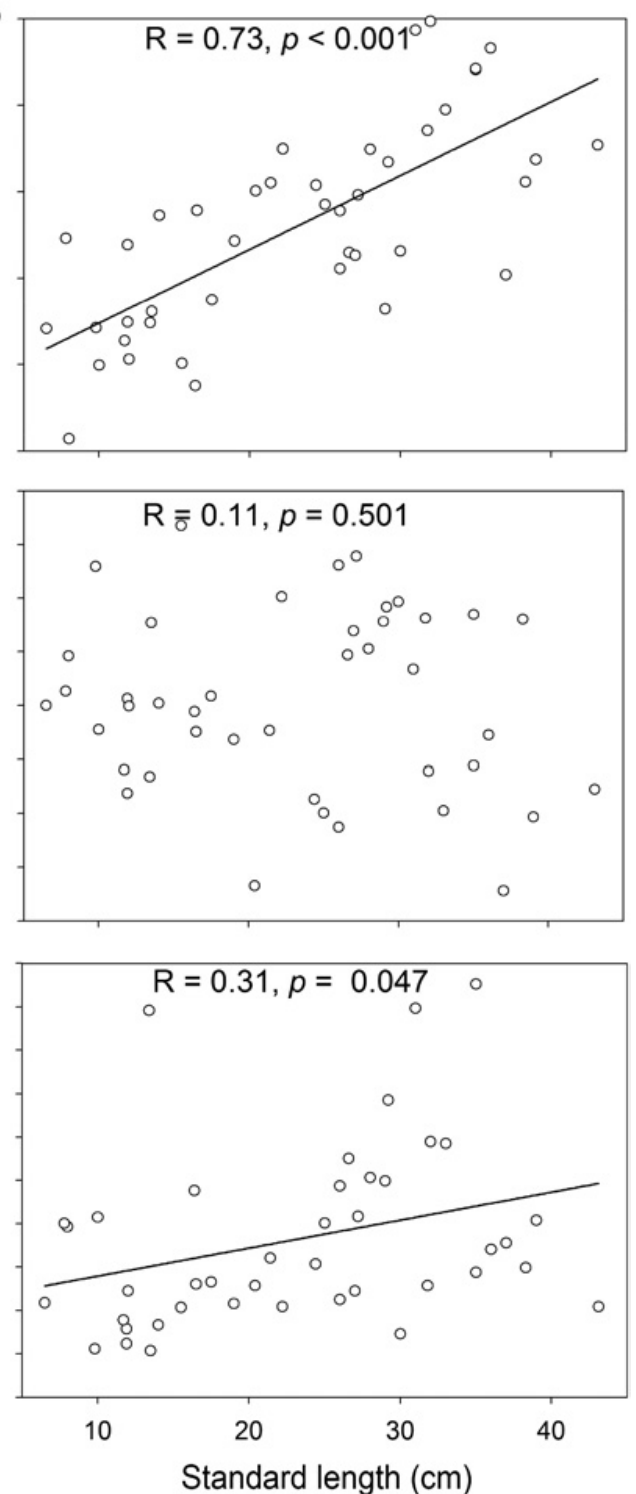

Fig. 3. Linear regression relationships between tigerfish Hydrocynus vittatus standard length, weight and $\delta^{13} \mathrm{C}$ (top panels), $\delta^{15} \mathrm{~N}$ (middle panels) and C:N ratios (bottom panels).

Why waste energy in diving deep and searching for prey that might be hidden, and then manipulating it so that it can be swallowed? It is probably far more efficient to feed on a passing clupeid or some other species in open water.

Stable isotope analysis showed that tigerfish fed on a variety of food sources including those that could not be found in stomach contents. Similar to the stomach content analysis, an ontogenetic dietary shift was observed for stable isotopes over different size classes, with significant differences being observed for the $\delta^{13} \mathrm{C}$ values, suggesting that they utilize different food sources. The dominant food sources identified by stable isotopes are in contrast to the stomach content analysis, which provides a snapshot of consumed food sources in that day or night, with the observed trends indicating prey items that may be temporarily abundant (Kadye and
Booth, 2012). However, stable isotope analysis managed to pick out the food sources that are commonly consumed by the different size classes over longer periods, i.e., up to three months (McCutchan et al., 2003), highlighting that crayfish are slowly becoming an important dietary food source.

From the current study, we can highlight that stomach content analysis of prey items consumed by predators is sometimes not feasible as stomachs might be empty. However, stomach content analysis provides additional taxonomic resolution information that is not readily afforded by stable isotope analysis such as identifying potential prey items that were not found in a particular area during sampling for stable isotope samples, e.g., Mormyrus longirostris. Hence, we can say that the two methods complement one another in providing dietary feeding information. 
Correlations between tigerfish stable isotope values and body size (i.e., mass and standard length) were investigated, with the absence of a systematic isotopic variation with mass and length being attributed to weak predator-prey size relationships, as suggested by Fry (1999). Nevertheless, positive relationships among $\delta^{15} \mathrm{~N}$ values with mass and standard length and $\mathrm{C}: \mathrm{N}$ ratios with standard length confirmed the intra-population trophic variations. An observation of Vander Zanden et al. (1998) in smallmouth bass within Lake Opeongo (Ontario, Canada), showed a positive relationship between $\delta^{13} \mathrm{C}$ values and body size, which indicated a change in feeding habits that fully supports our observation. With changes in body size, they suggested that there was a change in diet. However, Beaudoin et al. (2002) in the Boreal Plain Lakes of Canada observed that all the top predators, despite large differences in body size and trophic morphology, occupied similar TPs.

In conclusion, tigerfish in Lake Kariba showed remarkable dietary plasticity, identified by both stomach content and stable isotope analyses. This dietary plasticity showed an ontogenetic shift towards the fish prey preference and a decrease in the dominance of invertebrates with increasing tigerfish SL size. The invasive crayfish can be considered to be forming a significant portion of the tigerfish diet due to its increasing frequency in the diet of tigerfish, as identified by stable isotopes. This is similar to a study by Aquiloni et al. (2010) and Musseau et al. (2015) who found that invasive crayfish was the most important prey of the European eel Anguilla anguilla. With the current study highlighting that every size-class of crayfish is being preyed upon, this might be used as a complement to the traditional trapping or eradication methods of invasive crayfish (see Aquiloni et al., 2010; Musseau et al., 2015). Similar to our study, tigerfish can also be useful in controlling the population numbers of the redclaw crayfish. A high predator density in this system can strongly affect redclaw crayfish populations, possibly leading to their collapse, but not eradication. In future, studies similar to Blake and Hart (1993) on behavioural responses of the redclaw crayfish $C$. quadricarinatus to tigerfish and other predatory fishes chemical stimuli in the lake should be carried out for us to understand the crayfish responses to predation.

Acknowledgements. This study was funded by the Zimbabwe Research Council and the Vice Chancellor's Data Collection Fund, the University of Zimbabwe. The stable isotope analysis was carried out at the Stable Isotope Laboratory, Mammal Research Institute, University of Pretoria. We thank the Zimbabwe National Parks and Wildlife Management Authority, Lake Kariba Fisheries Research Institute and the University Lake Kariba Research Station staff for their technical support and assistance.

\section{Supplementary Material}

The supplementary material for this article can be found at http://dx.doi.org/10.1051/limn/2016033

\section{References}

Ahyong S.T. and Yeo D.C.J., 2007. Feral populations of the Australian red-claw crayfish (Cherax quadricarinatus von Martens). Biol. Invas., 9, 943-946.

Aquiloni L., Brusconi S., Cecchinelli E., Tricarico E., Giuseppe M., Paglianti A. and Gherardi F., 2010. Biological control of invasive populations of crayfish: the European eel (Anguilla anguilla) as a predator of Procambarus clarkii. Biol. Invas., 12, 3817-3824.

Baskar S., Narasimhan N., Swamidass D.G., Ravichelvan R., Sukumaran M. and Anandaraj T., 2012. Food and feeding habits of Penaeus monodon (Fabricius) from Mallipattinam Coast in Thanjavur Dist, Tamil Nadu, India. Int. J. Res. Biol. Sci., 3, 1-4.

Beaudoin C.P., Prepas E.E., Tonn W.M., Wassenaar L.I. and Kotak B.G., 2002. A stable carbon and nitrogen isotope study of lake food webs in Canada's Boreal Plain. Freshwat. Biol., 46, 465-477.

Bergamino L., Dalu T. and Richoux N.B., 2014. Spatial and temporal patterns in sediment organic matter composition within an estuarine environment: stable isotope and fatty acid signatures. Hydrobiologia, 732, 133-145.

Blake M.A. and Hart P.J.B., 1993. The behavioural responses of juvenile signal crayfish Pacifastacus leniusculus to stimuli from perch and eels. Freshwat. Biol., 29, 89-97.

Carvalho D.R., Castro D., Callisto M., Moreira M.Z. and Pompeu P.S., 2015. Isotopic variation in five species of stream fishes under the influence of different land uses. J. Fish Biol., 87, 559-578.

Coche A.G., 1974. Limnological study of a tropical reservoir. In: Balon, E.K. and Coche A.G. (eds.), Lake Kariba: a Man-made Tropical Ecosystem in Central Africa. Dr. W. Junk Publishers, The Hague, pp. 1-246.

Dalu T., Clegg B., Marufu L. and Nhiwatiwa T., 2012. The feeding habits of an introduced piscivore, Hydrocynus vittatus (Castelnau 1861) in a small tropical African reservoir. Pan-Am. J. Aquat. Sci., 7, 85-92.

Dalu T., Clegg B.W. and Nhiwatiwa T., 2013. A study of the ichthyofauna of a small tropical reservoir, south-eastern lowveld, Zimbabwe. Afr. J. Aquat. Sci., 38, 105-113.

Dalu T., Weyl O.L.F., Froneman P.W. and Wasserman R.J., 2016. Trophic interactions in an Austral temperate ephemeral pond inferred using stable isotope analysis. Hydrobiologia, 768, 81-94.

Dudgeon D., Arthington A.H., Gessner M.O., Kawabata Z-I., Knowler D.J., Lévêque C., Naiman R.J., Prieur-Richard A-H., Soto D., Stiassny M.L.J. and Sullivan C.A., 2006. Freshwater biodiversity: importance, threats, status and conservation challenges. Biol. Rev., 81, 163-182.

Feminella J.W. and Resh V.H., 1989. Submersed macrophytes and grazing crayfish: an experimental study of herbivory in a California freshwater marsh. Holarc. Ecol., 12, 1-8.

Fry B., 1999. Using stable isotopes to monitor watershed influences on aquatic trophodynamics. Can. J. Fish. Aquat. Sci., 56, 2167-2171.

Fry B. and Davis J., 2015. Rescaling stable isotope data for standardized evaluations of food webs and species niches. Mar. Ecol. Progr. Ser., 528, 7-17.

Gosse J.-P., 1986. Mochokidae. In: Daget J., Gosse J.-P. and Thys van den Audenaerde, D.F.E. (eds.) Check-list of 
the Freshwater Fishes of Africa (CLOFFA), ISNB, Brussels, MRAC, Tervuren and ORSTOM, Paris, pp. 402-414.

Hansson S., Hobbie J.E., Elmgren R., Larsson U., Fry B. and Johansson S., 1997. The stable nitrogen isotope ratio as a marker of food-web interactions and fish migration. Ecology, 78, 2249-2257.

Havel J.E., Kovalenko K.E., Thomaz S.M., Amalfitano S. and Kats L.B., 2015. Aquatic invasive species: challenges for the future. Hydrobiologia, 750, 147-170.

Hesslein R.H., Hallard K.A. and Ramlal P., 1993. Replacement of sulphur, carbon, and nitrogen in tissue of growing broad whitefish (Coregonus nasus) in response to a change in diet traced by $\delta^{34} \mathrm{~S}, \delta^{13} \mathrm{C}$, and $\delta^{15} \mathrm{~N}$. Can. J. Fish. Aquat. Sci., 50, 2071-2076.

Holling C.S., 1978. Adaptive Environmental Assessment and Management, Blackburn Press, Caldwell, USA.

Hudina S., Žganec K. and Hock K., 2015. Differences in aggressive behaviour along the expanding range of an invasive crayfish: an important component of invasion dynamics. Biol. Invas., 17, 3101-3112.

Hyslop E.J., 1980. Stomach contents analysis - a review of methods and their application. J. Fish Biol., 17, 411-430.

Iacarella J.C., Dick J.T.A. and Ricciardi A., 2015. A spatiotemporal contrast of the predatory impact of an invasive freshwater crustacean. Divers. Distrib., 21, 803-812.

ISP, 2016. Invasive species compendium, Available online at: http://www.cabi.org/isc/datasheet/89135

Jackson A.L., Inger R., Parnell A.C. and Bearshop S., 2011. Comparing isotopic niche widths among and within communities: SIBER-Stable Isotope Bayesian Ellipses in R. J. Anim. Ecol., 80, 595-602.

Jussila J., Ruokonen T.J., Syväranta J., Kokko H., Vainikka A., Makkonen J. and Kortet R., 2015. It takes time to see the menu from the body: an experiment on stable isotope composition in freshwater crayfishes. Knowl. Manag. Aquat. Ecosyst., 416, 25.

Kadye W.T. and Booth A.J., 2012. Integrating stomach content and stable isotope analyses to elucidate the feeding habits of non-native sharptooth catfish Clarias gariepinus. Biol. Invas., 14, 779-795.

Kenmuir D.H.S., 1971. An analysis of data on the tigerfish Hydrocynus vittatus Castelnau obtained from Kariba International Tigerfish Tournaments. Newsl. Limnol. Soc. South. Afr., 17, 33-38.

Kenmuir D.H.S., 1973. The Ecology of the Tigerfish, Hydrocynus Vittatus Castelnau in Lake Kariba, National Museums of Rhodesia (Zimbabwe), Bulawayo.

Kreps T.A., Larson E.R. and Lodge D.M., 2015. Do invasive rusty crayfish (Orconectes rusticus) decouple littoral and pelagic energy flows in lake food webs? Freshwat. Sci., 35.

Layman C.A., Quattrochi J.P., Peyer C.M. and Allgeier J.E., 2007. Niche width collapse in a resilient top predator following ecosystem fragmentation. Ecol. Lett., 10, 937-944.

Layman C.A., Araujo M.S., Boucek R., Hammerschlag-Peyer C.M., Harrison E., Jud Z.R., Matich P., Rosenblatt A.E., Vaudo J.J., Yeager L.A., Post D.M. and Bearhop S., 2012. Applying stable isotopes to examine food-web structure: an overview of analytical tools. Biol. Rev., 87, 545-562.

Marufu L.T., Phiri C. and Nhiwatiwa T., 2014. Invasive Australian crayfish Cherax quadricarinatus in the Sanyati basin of Lake Kariba: a preliminary survey. Afr. J. Aquat. Sci., 39, 233-236.
Matthes H., 1968. The food and feeding habits of tigerfish, Hydrocynus vittatus (Castelanau 1861), in Lake Kariba. Beaufortia, 15, 143-153.

McCutchan J.H. Jr., Lewis W.M. Jr., Kendall C. and McGrath C.C., 2003. Variation in trophic shift for stable isotope ratios of carbon, nitrogen, and sulfur. Oikos, 102, 378-390.

Mhlanga W., 2003. Food and feeding habits of tigerfish, Hydrocynus vittatus, in Lake Kariba, Zimbabwe. In: Palomares M.L.D., Samb B., Diouf T., Vakily J.M. and Paul D., (eds.), Fish Biodiversity. Local Studies as Basis for Global Inferences, Brussels, Belgium. ACP-EU Fisheries Research Report 14. 281p.

Musseau C., Boulenger C., Crivelli A.J., Lebel I., Pascal M., Boulêtreau S. and Santoul F., 2015. Native European eels as a potential biological control for invasive crayfish. Freshwat. Biol., 60, 636-645.

Mustamäki N., Cederberg T. and Mattila J., 2014. Diet, stable isotopes and morphology of Eurasian perch (Perca fluviatilis) in littoral and pelagic habitats in the northern Baltic Proper. Environ. Biol. Fishes, 97, 675-689.

Parnell A.C., Inger R., Bearhop S. and Jackson A.L., 2010. Source partitioning using stable isotopes: coping with too much variation. PLOS ONE, 5, e9672.

Peterson B.J. and Fry B., 1987. Stable isotopes in ecosystem studies. Annu. Rev. Ecol. Syst., 18, 293-320.

Pinnegar J.K. and Polunin N.V.C., 1999. Differential fractionation of $\Delta^{13} \mathrm{C}$ and $\Delta^{15} \mathrm{~N}$ among fish tissues: implications for the study of trophic interactions. Funct. Ecol., 13, 225-231.

Post D.M., Layman C.A., Arrington D.A., Takimoto G., Quattrochi J. and Montana C.G., 2007. Getting to the fat of the matter: models, methods and assumptions for dealing with lipids in stable isotope analyses. Oecologia, 152, 179-189.

Sala O.E., Chapin F.S. III, Armesto J.J., Berlow E., Bloomfield J., Dirzo R., Huber-Sanwald E., Huenneke L.F., Jackson R.B. and Kinzig A., 2000. Global biodiversity scenarios for the year 2100. Science, 287, 1770-1774.

Sanyanga R.A., 1996. Variations in abundance of Synodontis zambezensis (Pisces. Mochokidae) Peters 1852, in the inshore fishery of Lake Kariba. Fish. Res., 26, 171-186.

Souty-Grosset C., Anastácio P.M., Aquiloni L., Banha F., Choquer J., Chucholl C. and Tricarico E., 2016. The red swamp crayfish Procambarus clarkii in Europe: impacts on aquatic ecosystems and human well-being. Limnologica, 58, 78-93.

SPSS Inc., 2007. SPSS Release 16.0.0 for Windows, Polar Engineering and Consulting, SPSS Inc., Chicago.

Strayer D.L., 2010. Alien species in fresh waters: ecological effects, interactions with other stressors, and prospects for the future. Freshwat. Biol., 55, 152-174.

Takano M. and Subramaniam S.P., 1988. Some feeding observations on the predatory feeding habits of Hydrocynus vittatus Castelnau in Lake Kariba. In: Lewis D. (ed.) Predator-prey Relationships, Population Dynamics and Fisheries Productivities of Large African Lakes. CIFA Occasional papers 15, Food and Agricultural Organisation of the United Nations, Rome, pp. 130-139.

Tyser A.B. and Douthwaite R.J., 2014. Predation on invasive redclaw crayfish Cherax quadricarinatus by native 
fishes in the Kafue River, Zambia. Afr. J. Aquat. Sci., 39, 473-477.

Vanderklift M.A. and Ponsard S., 2003. Sources of variation in consumer-diet $\delta^{15} \mathrm{~N}$ enrichment: a meta-analysis. Oecologia, 136, 169-182.

Vander Zanden M.J., Cabana G. and Rasmussen J.B., 1997. Comparing trophic position of freshwater fish calculated using stable nitrogen isotope ratios $\left(\delta^{15} \mathrm{~N}\right)$ and literature dietary data. Can. J. Fish. Aquat. Sci., 54, 1142-1158.

Vander Zanden M.J., Hulshof M., Ridgway M.S. and Rasmussen J.B., 1998. Application of stable isotope techniques to trophic studies of age-0 smallmouth bass. Trans. Am. Fish. Soc., 127, 729-739.

von Martens E., 1868. Ueber einige ostasiatische Susswasserthiere. Archiv für Naturgeschichte, 34, 1-64.

Wendler F., Biss R. and Chucholl C., 2015. Population ecology of endangered white-clawed crayfish (Austropotamobius pallipes s. str.) in a small Rhithral River in Germany. Knowl. Manag. Aquat. Ecosyst., 416, 24.

Zengeya T.A. and Marshall B.E., 2007. Trophic interrelationships amongst cichlid fishes in a tropical African reservoir (Lake Chivero, Zimbabwe). Hydrobiologia, 592, 175-182. 